\title{
KONFLIK BATIN TOKOH UTAMA DALAM NOVEL KARYA RUWI MEITA TINJAUAN PSIKOLOGI SASTRA DAN RELEVANSINYA SEBAGAI BAHAN AJAR SASTRA INDONESIA DI SMA
}

\author{
Silmi Nur Azizah Tara, Muhammad Rohmadi, Kundharu Saddhono \\ Universitas Sebelas Maret \\ Surel: silmitara@student.uns.ac.id
}

\begin{abstract}
Abstrak: Tujuan penelitian ini adalah untuk mendeskripsikan: bentuk mekanisme pertahanan ego yang digunakan tokoh utama dalam menyelesaikan konflik batin, nilai-nilai pendidikan karakter, dan relevansi sebagai bahan pembelajaran sastra di SMA. Penelitian ini dilakukan dengan metode kualitatif deskriptif dan menggunakan pendekatan psikologi sastra. Hasil penelitian ini menunjukkan bahwa: 1) wujud konflik batin dalam novel Kaliluna: Luka di Salamanca Karya Ruwi Meita meliputi konflik menjauh-menjauh dan konflik mendekat-menjauh; (2) bentuk mekanisme pertahanan ego yang digunakan Kaliluna untuk menyelesaikan konflik batin yang dialami tokoh utama dalam novel Kaliluna: Luka di Salamanca berupa sublimasi, pengalihan, agresi, proyeksi, pembentukan rekasi, apatis, dan fantasi; (3) nilai-nilai pendidikan karakter yang terdapat dalam novel meliputi religius, toleransi, disiplin, kerja keras, kreatif, mandiri, rasa ingin tahu, semangat kebangsaan, bersahabat/komunikatif, gemar membaca, peduli sosial, dan bertanggung jawab; (4) novel Kaliluna: Luka di Salamanca karya Ruwi Meita relevan dengan materi ajar pembelajaran sastra Indonesia di SMA karena sesuai dengan kaidah materi ajar yang baik dan banyak memberikan nilai-nilai yang positif untuk direalisasikan dalam kehidupan seharihari.
\end{abstract}

Kata kunci: novel, psikologi sastra, nilai pendidikan karakter, pembelajaran sastra

\section{THE INNER CONFLICT OF THE MAIN CHARACTER IN KALILUNA: LUKA DI SALAMANCA BY RUWI MEITA REVIEW OF LITERATURE PSYCHOLOGY AND ITS RELEVANCE AS LITERATURE MATERIAL OF INDONESIAN LITERATURE IN SENIOR HIGH SCHOOL}

\begin{abstract}
The purpose of this study was to describe: the form of ego defense mechanism used by the main character in resolving inner conflicts, character education values, and relevance as literary learning material in high school. This research was carried out with qualitative descriptive method and using literary psychology approach. The results of this study indicate that: 1) the form of inner conflict in the Kaliluna novel: Luka di Salamanca by Ruwi Meita includes the conflict away and the conflict approaching; (2) the form of the ego defense mechanism used by Kaliluna to resolve inner conflicts experienced by the main character in the novel Kaliluna: Luka di Salamanca in the form of sublimation, diversion, aggression, projection, reaction formation, apathy, and fantasy; (3) the values of character education contained in the novel include religious, tolerance, discipline, hard work, creative, independent, curiosity, national spirit, friendly / communicative, fond of reading, social care, and responsibility; (4) Kaliluna : Luka di Salamanca is relevant to teaching materials for learning Indonesian literature in high school because it is in accordance with the principles of good teaching materials and provides many positive values to be realized in daily life
\end{abstract}

Keywords: novel, literary psychology, character education value, literatery education

\section{PENDAHULUAN}

Suatu hasil karya sastra dapat dalamnya mengandung kenikmatan dan dikatakan memiliki nilai sastra bila di manfaat, bentuk bahasanya baik dan indah, 
dan susunan kata beserta isinya dapat menimbulkan perasaan haru dan kagum di hati pembacanya, pendapat ini dikemukakan oleh Horatius yang merupakan seorang kritikus sastra pada zaman Romawi kuno bahwa karya sastra memiliki dua fungsi yaitu Dulce et Utile, yaitu indah dan menghibur serta membangun dan mengajarkan sesuatu.

Karya sastra yang selalu diminati masyarakat luas dari waktu ke waktu salah satunya adalah novel. Novel merupakan suatu cerita fiksi yang memiliki perbedaan diantara karya sastra lainnya. Novel merupakan cerita menengah yang menggambarkan realitas kehidupan yang masuk akal dengan mengetengahkan tokoh heroik beserta perubahan nasibnya dan terbagi dalam beberapa episode kehidupan (Herman J. Waluyo, 2002: 36-37).

Berdasar pendapat ahli di atas, dapat disimpulkan bahwa novel berupa prosa fiksi yang mengungkapkan situasi serta karakter tokoh secara mendetail serta mengetengahkan beberapa karakter dalam sebuah kehidupan nyata yang bersifat memperluas pengalaman dengan menghadirkan tokoh heroik yang problematik.

Konflik yang dihadirkan oleh seorang pengarang dalam cerita biasanya tidak luput dari kenyataan bahwa keberadaannya memang merupakan bagian dari kehidupan manusia. Sebagai makhluk sosial yang hidup berdampingan, seringkali timbul berbagai konflik yang dipicu oleh beragam motif. Ratna (2011:324) mengungkapkan bahwa manusia perlahan akan kehilangan pengendalian diri ketika tingkat peradaban mencapai suatu kemajuan sehingga memicu suatu konflik.

Banyaknya permasalahan pada kehidupan nyata yang disuguhkan seorang penulis melalui karyanya menjadikan sebuah karya sastra mengandung aspekaspek kejiwaan yang sangat kaya. Dengan demikian, untuk mengimbangi hal tersebut maka diperlukan peran psikologi sastra. Psikologi sastra sendiri merupakan suatu ilmu yang memiliki kreativitas dan bersifat interdisipliner. Tujuan dari psikologi sastra adalah untuk memahami aspek-aspek kejiwaan yang terkandung dalam suatu karya.

Novel Kaliluna: Luka di Salamanca merupakan karya dari seorang penulis bernama Ruwi Meita. Novel setebal 270 halaman ini diterbitkan oleh Moka Media pada tahun 2014. Novel berjudul Kaliluna: Luka di Salamanca ini menarik untuk dikaji secara psikologi sastra karena bila ditinjau dari permasalahanpermasalahan yang terdapat dalam novel. Aspek psikologis yang dialami oleh tokoh utama pada novel Kaliluna: Luka di Salamanca tercermin dari banyaknya permasalahan yang dialami oleh tokoh utama hingga memunculkan konflik batin. Konflik yang ditampilkan dalam cerita ini tidak begitu rumit, namun menimbulkan rasa keingintahuan peneliti untuk mengupas secara lebih mendalam. Selain itu, novel ini juga sarat akan nilai-nilai pendidikan karakter yang dikemas dengan menarik dan sangat menyentuh.

Tujuan menganalisis sastra dengan tinjauan psikologi sastra adalah untuk memahami aspek kepribadian tokoh utama yang terkandung di dalam karya sebagai bagian masalah yang diangkat pengarang dalam karyanya. Selain itu dalam karya sastra berupa novel yang merupakan gambaran kehidupan manusia, tentunya banyak nilai-nilai pendidikan karakter yang baik. Hal tersebut membuat suatu novel menjadi lebih berbobot dan bermutu. Jadi, selain menghibur, karya sastra novel juga harus memiliki manfaat lain sehingga dapat menginspirasi para pembacanya. Kemendiknas menjelaskan bahwa nilai-nilai pendidikan karakter yang dikembangkan dalam dunia pendidikan didasarkan pada 4 sumber, yaitu agama, Pancasila, budaya bangsa, dan tujuan pendidikan nasional itu sendiri. Dari keempat sumber tersebut bisa dirumuskan 18 nilai-nilai karakter umum yaitu; religius, jujur, toleransi, disiplin, kerja keras, kreatif, mandiri, demokratis, rasa 
ingin tahu, semangat kebangsaan, cinta tanah air, menghargai prestasi, bersahabat/komunikatif, cinta damai, gemar membaca, peduli lingkungan, peduli sosial, dan tanggung jawab.

Novel Kaliluna: Luka di Salamanca karya Ruwi Meita juga memiliki nilai-nilai yang dapat diteladani. Nilai-nilai pendidikan karakter tersebut sangat baik digunakan dalam membangun karakter anak bangsa.

Pembelajaran sastra memiliki manfaat penting dalam pembentukan karakter pada peserta didik. Menurut Nurhayati (dalam Wibowo, 2012:19), pengajaran sastra memiliki pertautan erat dengan pendidikan karakter karena pengajaran sastra dan sastra pada umumnya, secara hakiki membicarakan nilai hidup dan kehidupan yang mau tidak mau berkaitan dengan pembentukan karakter manusia.

Penelitian ini difokuskan pada konflik batin yang dialami tokoh utama dalam novel Kaliluna: Luka di Salamanca karya Ruwi Meita. Dari beberapa konflik yang dialami tokoh utama dalam novel Kaliluna: Luka di Salamanca, peneliti menemukan beberapa hal yang menyebabkan kejiwaan tokoh utama terguncang, sehingga melakukan segala upaya dalam bentuk sikap dan perbuatan sebagai wujud perlindungan diri dari kehidupan yang tidak disukai. Ditilik dari kasus tersebut, peneliti akan menggunakan pendekatan psikoanalisis yang difokuskan pada teori Sigmund Freud.

Berdasarkan uraian di atas, maka penelitian ini mengambil judul "Konflik Batin Tokoh Utama dalam Novel Kaliluna: Luka di Salamanca Karya Ruwi Meita Tinjauan Psikologi Sastra dan Relevansinya sebagai Bahan Ajar Sastra Indonesia di SMA". Peneliti bermaksud untuk melakukan penelitian secara mendalam novel Kaliluna: Luka di Salamanca dengan pendekatan psikologi sastra

\section{METODE PENELITIAN}

Penelitian ini dilaksanakan selama enam bulan, yaitu dari bulan Februari 2018 sampai dengan Juli 2018. Penelitian ini merupakan penelitian kualitatif deskriptif dengan menggunakan pendekatan psikologi sastra. Data dan sumber data yang digunakan adalah kata, frasa, kalimat, paragraf/alinea, wacana, yang ada dalam novel Kaliluna: Luka di Salamanca karya Ruwi Meita yang menunjukkan konflik batin tokoh. Selain itu data diperoleh juga dari hasil wawancara dengan guru SMA N 2 Surakarta yang telah membaca novel Kaliluna: Luka di Salamanca. Pengambilan subjek penelitian dilakukan dengan teknik purposive sampling. Pengumpulan data dilakukan dengan analisis dokumen dan wawancara. Uji validitas data dalam penelitian ini menggunakan triangulasi triangulasi metode. Teknik analisis data yang digunakan adalah teknik analisis model mengalir yang dikemukakan oleh Miles dan Huberman.

\section{HASIL DAN PEMBAHASAN}

\section{Wujud Konflik Batin Tokoh Utama dalam Novel Kaliluna: Luka di Salamanca}

Konflik batin merupakan permasalahan yang timbul akibat adanya pertentangan batin yang terjadi di dalam diri seorang tokoh. Keadaan yang membuatnya mengalami kebingungan karena harus memilih satu diantara dua atau beberapa pilihan tentunya akan membuat seorang tokoh mengalami kebimbangan dan kebingungan. Situasi konflik merupakan situasi dimsaat seseorang merasa bimbang atau bingung karena harus memilih antara dua atau beberapa motif yang muncul bersamaan. Konflik dapat dibedakan menjadi beberapa bentuk menurut Dirgagunarsa (dalam Sobur, 2013: 292-293) yaitu (1) konflik mendekat-mendekat (approach-approach conflict) merupakan konflik yang timbul apabila suatu ketika terdapat dua motif yang kesemuanya positif (menyenangkan, 
menguntungkan), sehingga muncul kebimbangan untuk memilih satu diantaranya. Memilih satu motif berarti mengorbankan atau mengecewakan motif lain yang tidak dipilih; (2) konflik mendekat-menjauh (approach-avoidance conflict) merupakan konflik yang timbul jika dalam waktu yang sama timbul dua motif yang berlawanan mengenai satu objek, motif yang satu positif (menyenangkan), yang lain negatif (merugikan, tidak menyenangkan); dan (3) konflik menjauh-menjauh (avoidanvceavoidance conflict) merupakan konflik yang terjadi apabila pada saat yang bersamaan, timbul dua motif yang negatif, dan muncul kebimbangan karena menjauhi motif yang satu berarti harus memenuhi motif lain yang juga negatif.

Konflik batin dalam novel Kaliluna: Luka di Salamanca menampilkan berbagai permasalahan yang dihadapi Kaliluna dalam hidupnya. Konflik yang dialami Kaliluna mencakup dua dari tiga jenis koflik yang disampaikan oleh Dirgagunarsa.

Konflik batin yang pertama yaitu konflik menjauh-menjauh. Konflik menjauh-menjauh dialami Kaliluna saat ia mencoba mempertahankan hidupnya dari si pemerkosa yang hendak membunuhnya. Kaliluna tidak punya pilihan lain selain menggunakan busur dan panahnya untuk membunuh si pemerkosa sebelum orang itu membunuhnya terlebih dahulu. Semenjak saat itu kehidupannya berubah, ia tak lagi memandang panah dengan cara yang sama. Kemudian rasa tidak nyaman terhadap-orang-orang baru dalam hidupnya menunjukkan bahwa Kaliluna juga mengalami konflik menjauh-menjauh. Selain itu, tawaran Ibai untuk mengajaknya membeli permen juga merupakan konflik dengan jenis yang sama. Ia harus memilih untuk pergi bersama Ibai agar merasa aman dari Margarita, atau menolak tawaran Ibai dan menghadapi Margarita yang membuatnya merasa tidak nyaman. Kedua pilihan tersebut sama-sama tidak menguntungkan bagi Kaliluna.
Kebimbangan Kaliluna dalam memutuskan untuk kembali ke Indonesia atau tetap tinggal di Salamanca juga merupakan konflik menjauh-menjauh. Kaliluna harus memilih untuk kembali ke Indonesia dan menyakiti Ibai, atau tetap tinggal di Salamanca namun menyakiti Arya dan keluarganya di Indonesia. Setiap pilihan yang dibuat Kaliluna akan menyakiti salah satu pihak.

Konflik batin yang selanjutnya yaitu konflik mendekat-menjauh. Konflik tersebut terjadi saat Kaliluna dihadapkan oleh pilihan-pilihan yag mempunyai sisi positif dan negatif. Mulai dari Kaliluna yang menginginkan permen yang dibawa Ibai, namun ia tidak bisa begitu saja menerimanya karena tidak mengenal Ibai. Dilanjutkan dengan Kaliluna yang gelisah karena ia benar-benar menginginkan permen yang ditinggalkan Ibai dan tawaran Ibai untuk meminjaminya uang, hingga tawaran makan siang oleh Maite.

Konflik batin mendekat-menjauh terus terjadi bahkan saat Kaliluna menghadapi tarumanya. Banyak pilihanpilihan yang membuatnya bimbang dalam mengambil keputusan. Kaliluna bisa saja tidak mengusahakan apapun dan tetap berada di zona amannya, namun ia tidak bisa menyembuhkan traumanya. Atau ia harus berusaha menyembuhkan traumanya, namun ia yakin respon yang diberikan tubuhnya pasti tidak baik. Kedua pilihan tersebut memiliki keuntungan dan kekurangan masing-masing.

Konflik batin yang dialami Kaliluna silih berganti mulai dari awal cerita hingga akhir cerita. Penulis mengemas situasi konflik tersebut bersama dengan penyelesaian konflik, sehingga Kaliluna selalu dapat menyelesaikan konflik batinnya. Meskipun cara yang digunakan tidak selalu positif.

Penelitian ini sejalan dengan penelitian Rini (2014) yang menyatakan bawa ego harus bekerja untuk menyeimbangkan superego dan dorongan id Berdasarkan hal tersebut, dapat diambil kesimpulan bahwa konflik batin yang 
dialami tokoh utama timbul ketika Kaliluna merasakan kenyataan yang dihadapinya tidak sesuai dengan harapan atau tidak seimbangnya id, ego, dan superego. Konflik batin yang dialami Kaliluna membuat ego dalam dirinya harus menyeimbangkan dorongan id dan superego. Hal tersebut berdampak pada sikap Kaliluna dalam bertindak mengambil keputusan.

\section{Bentuk Mekanisme Pertahanan Ego Kaliluna dalam Menyelesaikan Konflik Batin dalam Novel Kaliluna: Luka di Salamanca}

Konflik batin adalah suatu kejadian yang sering dialami manusia hingga membuat mereka berada dalam dua pilihan atau lebih. Seseorang tidak dapat mengambil semua pilihan tersebut dan hanya bisa memilih salah satu dari pilihanpilihan yang tersedia. Setiap manusia yang mengalami konflik batin pasti berusaha mencari cara untuk mengatasi konflik batin tersebut. Konflik yang berbeda tentu memiliki cara penyelesaian yang berbeda.

Novel Kaliluna: Luka di Salamanca menampilkan bagaiman tokoh Kaliluna menggunakan beberapa mekanisme pertahanan ego untuk mengatasi konflik batin yng dialaminya. Namun tidak semua mekanisme pertahanan ego yang digunakannya merupakan cara yang positif. Beberapa mekanisme pertahanan ego yang digunakan Kaliluna justru menyakiti dirinya sendiri dan orang-orang di sekitarnya. Kaliluna meggunakan mekanisme pertahanan ego dalam bentuk agresi saat ia harus mempertahankan hidupnya. Kaliluna memilih untuk mempertahankan hidupnya dengan membunuh si pemerkosa menggunakan panah yang berada di atas tasnya.

Mekanisme pertahanan ego yang digunakan Kaliluna selanjutnya adalah sublimasi. Sublimasi dilakukan oleh Kaliluna saat ia merasa tidak mampu menerima dirinya sendiri dengan mengabaikan orang-orang di sekitarnya. Selain itu, perasaan tidak nyaman terhadap perhatian orang-orang di sekitarnya membuat Kaliluna melampiaskannya dengan sikap menutup diri dan tidak mau berkomuniksi dengan orang-orang di sekitarnya.

Selanjutnya, Kaliluna menggunakan mekanisme pertahanan diri berupa pengalihan atau displacement untuk mengatasi kecemasan yang diterimanya. Kaliluna memilih untuk mengalihkan rasa tidak nyaman dalam dirinya dengan melukai jarinya, sehingga Kaliluna akan lebih fokus pada rasa sakit di jarinya dibandingkan dengan kegelisahannya .

Proyeksi dilakukan tokoh utama sebagai pertahanan ego saat ia menyalahkan Frida atas sikap buruknya pada Frida selama ini. Kaliluna merasa mendiamkan dan mengabaikan Frida adalah hal yang tepat karena Frida dulu pernah meninggalkannya saat ia bahkan masih terlalu kecil.

Selain Frida, Kaliluna juga melakukannya pada Ibai. Kaliluna yang merasa dirinya tidak sanggup melawan traumanya sendiri justru menyalahkan Ibai yang selalu peduli dan berusaha membantu Kaliluna melawan traumanya itu.

Mekanisme pertahanan ego yang dilakukan oleh tokoh utama selanjutnya yaitu pembentukan reaksi atau reaction formation. Mekanisme pertahanan ego pembentukan reaksi yang dilakukan ole $\mathrm{h}$ Kaliluna adalah penolakannya pada permen jeli yang ditawarkan Ibai. Padahal Kaliluna menginginkan permen tersebut. Sikap Kaliluna yang sangat bertolak belakang dengan keinginannya menunjukkan bahwa ia menggunakan bentuk pertahanan ego berupa pembentukan reaksi.

Selanjutnya mekanisme pertahanan ego yang digunakan oleh Kaliluna adalah apatis. Kaliluna yang pasrah karena ia tidak bisa melakukan apa-apa terpaksa menerima tawaran Ibai untuk mengantarnya pulang dengan taksi. Rekasi menurut yang ditunjukkan Kaliluna saat Ibai menyuruhnya masuk dan mengantarkan pulang menunjukkan bentuk 
pertahanan ego berupa apatis.

Mekanisme pertahanan ego terakhir yang sering digunakan oleh tokoh Kaliluna adalah fantasi. Dalam mempertahankan dirinya dari kecemasan, Kaliluna membentuk gelembung-gelembung tak kasat mata sebagai dunianya untuk melindunginya dari rasa cemas.

Berdasarkan uraian diatas maka dapat disimpulkan bahwa kondisi kejiwaan Kaliluna mempengaruhi keputusan pemilihan penggunaan mekanisme pertahanan diri. Tidak hanya menggunakan mekanisme pertahanan ego secara positif, terkadang Kaliluna juga menggunakan cara-cara yang menyakiti dirinya atau orang-orang di sekitarnya untuk menekan kecemasannya. Dapat disimpulkan bahwa keterkaitan konflik batin, keseimbangan id, ego, dan superego, serta cara bersikap Kaliluna merupakan hal yang tidak dapat dipisahkan karena untuk mengatasi konflik batin Kaliluna harus berpikir dengan jernih agar tidak terjadi konflik baru atas reaksi yang diberikan.

\section{Nilai-nilai Pendidikan Karakter dalam Novel Kaliluna: Luka di Salamanca karya Ruwi Meita}

Sebuah karya sastra selain menghibur juga harus memiliki fungsi mendidik pembaca melalui cerita dan pesan yang terkandung di dalamnya. Maka dari itu, sebuah karya sastra yang baik adalah sebuah karya yang di dalamnya selain dapat menghibur pembaca juga mengandung nilai-nilai pendidikan. Penulis ataupun pengarang dapat menyisipkan nilai-nilai pendidikan karakter ke dalam karyanya melalui tokohtokoh secara tersirat maupun tersurat.

Nilai pendidikan karakter dalam sastra biasanya muncul melalui amanat yang berupa pesan moral. Pesan moral tersebut tentunya dapat dijadikan sebagai teladan. Nilai pendidikan karakter dalam novel Kaliluna Luka di Salamanca diantaranya adalah religius, toleransi, kerja keras, kreatif, mandiri, rasa ingin tahu, gemar membaca, peduli sosial, dan tanggung jawab. Nili-nilai tersebut dapat disimak melalui tindakan para tokoh yang tampak pada cerita. Berikut deskripsi nilai pendidikan karakter dalam novel Kaliluna Luka di Salamanca karya Ruwi Meita. Nilai pendidikan karakter yang digunakan sebagai acuan penelitian ini adalah menggunakan nilai pendidikan karakter yang bersumber dari Kemendiknas (2010: 9). Dari 18 nilai pendidikan karakter yang tercantum dalam Kemendiknas tahun 2010, terdapat 9 nilai pendidikan karakter yang terdapat dalam novel Kaliluna: Luka di Salamanca.

\section{Religius}

Ibai kemudian duduk di antara dua wanita itu. Maite memberi isyarat kepada Ibai untuk memimpin berdoa. Semula Ibai menggeleng tetapi Maite menekannya dengan tatapan tegas seakan berkata seorang laki-laki harus bisa memimpin doa. Ibai lalu melipat tangan dan menunduk. Kaliluna paham jika mereka hendak berdoa...(KLS, 2014: 139)

\section{Toleransi}

"No tengas miedo, Kali," kata Pilar lembut. Dia mengarahkan tangan Kali lalu menyentuhkannya ke busur itu.(KLS, 2014: 200)

\section{Kerja Keras}

“... Untuk itu aku berlatih siang dan malam. Aku bahkan menambah porsi latihanku, lebih banyak dari teman-temanku yang lain..."(KLS, 2014: 185)

\section{Kreatif}

Malam ini Frida ingin berkspermen dengan membuat tempe dri biji matahari. Dia membuka kantong kedelai dan memasukkannya dalam baskom besar. (KLS, 2014: 120) 
Kaliluna tetap mencuci piringnya sendiri lalu masuk ke kamarnya. Dia inginmengunyah permen jeli sebelum menggosok gigi.(KLS, 2014: 122)

\section{Rasa Ingin Tahu}

Ibai suka datang ke klub ini di waktu senggang. Bukan untuk berlatih namun untuk memerhatikan.

Sejak kecil Ibai adalah seorang pemerhati yang baik. Matanya jeli dan pikirannya terus berputar seperti jarum jam yang tak lelah. ...(KLS, 2014: 12)

\section{Gemar Membaca}

Pilar melirik buku yang ada di tangan Ibai.

"Kenapa setiap hari kamu jatuh cinta dan patah hati sekaligus?"

"Heh?"

"Veinte Poemas de Amory Una Cancian Desesperada. Kamu selalu membawanya." (KLS, 2014: 13)

\section{Peduli Sosial}

Margarita mengangguk. Dia berjalan terhuyung-huyung.

"Bolehkah aku bawakan bawaanmu?" kata Kaliluna yang semakin khawatir melihat Margarita. Tanpa menunggu persetujuan Margarita, Kaliluna segera meraih kantong-kantong yang berjubelan di tangan Margarita. (KLS, 2014: 159)

\section{Tanggung Jawab}

"Tidak, sejak Papaku meninggal aku harus mengurusi toko dan mamaku. Aku sudah melupakan keinginan untuk kuliah."'(KLS, 2014 125)

Nilai pendidikan karakter ini dapat dijadikan sebagai pedoman siswa untuk mengembangkan perilaku positif. Nilai pendidikan karakter yang terdapat dalam novel dapat dilihat dari perwatakan dan perilaku tokoh.
Relevansi Novel Kaliluna: Luka di Salamanca Karya Ruwi Meita sebagai bahan ajar Sastra Indonesia di SMA

Bahan ajar adalah seperangkat materi pembelajaran yang emngacu pada kurikulum yang digunakan (dalam hal ini adalah silabus mata pelajaran) dalam rangka mencapai standar kompetensi dan kompetensi dasar yang telah ditentukan (Lestari, 2013: 2). Maka dari itu dalam menyusun sebuah bahan ajar harus berpedoman pada kurikulum yang berlaku. Sehingga bahan ajar tersebut dapat digunakan untuk mencapai kompetensi inti dan kompetensi dasar. Sedangkan Rahmanto (1988:27) menjelaskan bahwa pemilihan bahan pengajaran sastra juga harus mempertimbangkan tiga aspek penting, yaitu segi bahasa, segi kematangan jiwa (psikologi), dan sudut latar belakang kebudayaan.

Berdasarkan penelitian yang telah dilakukan terhadap novel Kaliluna: Luka di Salamanca karya Ruwi Meita, ketiga aspek tersebut dapat ditemukan dalam novel ini.

Pertama, yaitu dari segi bahasa, novel Kaliluna: Luka di Salamanca karya Ruwi Meita memenuhi aspek tersebut. Kalimat dan bahasa yang digunakan dalam novel tersebut sesuai dengan kaidah kebahasaan. Pemilihan kata-kata yang digunakan juga wajar apabila digunakan sebagai bahan ajar di SMA. Selain itu, pengarang juga menampilkan diksi-diksi yang bervariasi untuk menambah wawasan kebahasaan siswa.

Kedua, berdasarkan aspek kematangan jiwa (psikologis), cerita yang disajikan pengarang merupakan cerminan realitas yang sesuai dengan tahap perkembangan usia siswa SMA. Pengarang menuliskan cerita berdasarkan apa yang terjadi di kehidupan nyata pada seorang remaja yang mengalami masalah keluarga dan mental. Dimensi fisiologis tokohtokoh yang dihadirkan juga memiliki kedekatan dengan perkembangan fisiologis siswa SMA.

Ketiga, berdasarkan latar belakang 
budaya siswa, peristiwa di dalam cerita juga terjadi pada kehidupan sehari-hari siswa. Hal ini berarti kejadian dalam cerita juga terjadi di lingkungan sosial siswa. Zaman sekarang ini tak jarang siswa yang mengalami peristiwa yang juga dialami oleh tokoh utama. Novel ini mengajarkan pada siswa untuk memiliki pandangan lain terhadap suatu masalah, yaitu untuk bangkit dari hal buruk yang menimpanya.

Relevansi isi novel Kaliluna: Luka di Salamanca karya Ruwi Meita sebagai bahan ajar sastra Indonesia di SMA. Relevansi tersebut mencakup isi cerita yang menarik dan memberikan motivasi kepada siswa-siswa SMA. Cerita dalam novel Kaliluna: Luka di Salamanca dapat menjadi bacaan yang sesuai untuk anak usia sekolah karena dari segi isi berkaitan dengan dunia anak remaja dan kehidupan keluarga. Novel ini tergolong menarik karena mengisahkan tentang seorang tokoh yang berusaha bangkit dari keterpurukannya dan melawan rasa traumanya.

Pada kurikulum 2013 mata pelajaran Bahasa Indonesia di SMA kelas XII terdapat kompetensi dasar yang menuntut siswa untuk mampu memahami dan menganalisis teks novel. Jadi pemilihan bahan ajar juga harus disesuaikan dengan kurikulum yang berlaku. Selain itu, guru juga dituntut untuk mampu menghadirkan bahan ajar yang menarik minat siswa. Novel Kaliluna: Luka di Salamanca relevan dijadikan sebagai bahan ajar di SMA terutama kelas XII karena cerita di dalamnya memuat peristiwa yang menarik bagi siswa. Analisis psikologi sastra mengenai kepribadian tokoh utama dan nilai-nilai pendidikan karakter juga relevan digunakan sebagai bahan ajar. Nilai pendidikan karakter dengan pengajaran sastra Indonesia di SMA. Pendidikan karakter dipastikan memiliki relevansi dengan pembelajaran di sekolah. Sehingga dengan menggunakan novel ini secara tidak langsung pembaca atau siswa dapat meneladani cara pembentukan karakter Kaliluna tersebut. Ini menjadikan salah satu kelebihan dari novel Kaliluna: Luka di Salamanca bahwa novel ini bukan hanya menjadi novel pembangun jiwa, tetapi juga merupakan novel yang penuh dengan nilai pendidikan karakter, kelebihan dari novel ini belum tentu dimiliki oleh novel lain. Dengan banyaknya nilai pendidikan karakter yang dapat kita ambil dari novel Kaliluna: Luka di Salamanca, novel ini patut dijadikan sebagai alternatif bahan pembelajaran sastra di SMA.

\section{SIMPULAN}

Berdasarkan analisis data yang dilakukan terhadap novel Kaliluna: Luka di Salamanca karya Ruwi Meita dapat disimpulkan bahwa wujud konflik batin dalam nov el Kaliluna: Luka di Salamanca karya Ruwi Meita meliputi konflik menjauh-menjauh (avoidanceavoidance conflict) dan konflik mendekat menjauh (approaching-avoidance conflict). Konflik pertama yang dialami oleh Kaliluna yaitu konflik menjauhmenjauh (avoidance-avoidance conflict) berupa; (1) Kaliluna yang berusaha menyelamatkan nyawanya, (2) Rasa tidak nyaman Kaliluna terhadap orang-orang baru, dan (3) Kebimbangan Kaliluna saat dihadapkan pada dua pilihan. Sementara konflik mendekat menjauh (approachingavoidance conflict) berupa; (1) Kebimbangan Kaliluna saat dihadapkan dengan pilihan, (2) Kebimbangan Kaliluna untuk menemui Ibai, (3) Kebimbangan Kaliluna untuk menemui Ibai, (4) Kaliluna yang berusaha menyembuhkan traumanya.

Penelitian ini sejalan dengan penelitian Rini (2014) yang menyatakan bawa ego harus bekerja untuk menyeimbangkan superego dan dorongan id Berdasarkan hal tersebut, dapat diambil kesimpulan bahwa konflik batin yang dialami tokoh utama timbul ketika Kaliluna merasakan kenyataan yang dihadapinya tidak sesuai dengan harapan atau tidak seimbangnya $i d$, ego, dan superego. Konflik batin yang dialami Kaliluna membuat ego dalam dirinya harus menyeimbangkan dorongan id dan 
superego. Hal tersebut berdampak pada sikap Kaliluna dalam bertindak mengambil keputusan.

Kaliluna menggunakan mekanisme pertahanan ego sebagai bentuk penyelesaian dari konflik bati yang dialaminya. Beberapa cara mengatasi konflik batin yang dialami Kaliluna adalah 1) Sublimasi, 2) Displacement (Pengalihan), 3) Agresi, 4) Proyeksi, 5) Pembentukan reaksi, 6) Apatis, 7) Fantasi. Cara mengatasi konflik batin melalui berbagai macam hal ini sejalan dengan penelitian yang dilakukan Ni'mah (2017) yang meneliti tentang mekanisme pertahanan ego tokoh utama dalam film Mo Shiranai, dalam penelitian Ni'mah solusi konflik batin yang dipilih tokoh dengan mekanisme pertahanan ego untuk mengurangi kecemasan pada diri Fukushima Akira. Perbedaan dengan penelitian saya adalah objek penelitian yang berupa novel, konflik, solusi pemecahan masalah, nilai pendidikan karakter, sampai pada relevansi dalam pembelejaran di SMA.

Penelitian ini juga sejalan dengan penelitian Ambarini (2008) yang meneliti tentang konflik batin yang ada di novel Poor Man's Orange, dalam penelitian Ambarini solusi konflik batin yang dipilih tokoh dengan mekanisme pertahanan ego untuk mengurangi kecemasan pada diri Dolour Darcy. Perbedaan dengan penelitian saya ada pada pembahasan nilai pendidikan dan relevansi sebagai bahan ajar sastra di SMA.

Berdasarkan uraian diatas maka dapat disimpulkan bahwa kondisi kejiwaan Kaliluna mempengaruhi keputusan pemilihan penggunaan mekanisme pertahanan diri. Tidak hanya menggunakan mekanisme pertahanan ego secara positif, terkadang Kaliluna juga menggunakan cara -cara yang menyakiti dirinya atau orang-orang di sekitarnya untuk menekan kecemasannya. Dapat disimpulkan bahwa yang sesuai dengan keterkaitan konflik batin, keseimbangan $i d$, ego, dan superego, serta cara bersikap Kaliluna merupakan hal yang tidak dapat dipisahkan karena untuk mengatasi konflik batin Kaliluna harus berpikir dengan jernih agar tidak terjadi konflik baru atas reaksi yang diberikan.

Nilai pendidikan karakter yang terkandung dalam novel Kaliluna: Luka di Salamanca karya Ruwi Meita meliputi: (a) religius; (b) toleransi; (c) kerja keras; (d) disiplin; (e) kreatif; (f) mandiri; (g) semnagat kebangsaan, (h) bersahabat/komunikatif, (i) rasa ingin tahu; (j) gemar membaca; (k) peduli sosial; (l) tanggung jawab. Dari dua belas nilai pendidikan karakter yang terdapat pada cerita di dalam novel Kaliluna: Luka di Salamanca karya Ruwi Meita, terdapat empat nilai pendidikan karakter yang menjadi nilai dominan yang ada dalam cerita tersebut. Keempat nilai pendidikan karakter tersebut antara lain: (1) kerja keras; (2) disiplin; (3) mandiri; dan (4) peduli sosial. Nilai-nilai tersebut saling melebur dalam cerita yang dimainkan oleh setiap tokoh-tokohnya. Berdasarkan data dari hasil analisis dan wawancara dari para informan mengenai materi pembelajaran Bahasa Indonesia maka dapat disimpulkan bahwa novel Kaliluna: Luka di Salamanca karya Ruwi Meita mempunyai nilai pendidikan karakter yang baik dan bisa digunakan sebagai alternatif dalam pembelajaran sastra Indonesia di SMA khususnya kelas XII semester genap. Kesesuaian ini berdasarkan kompetensi inti dan kompetensi dasar yang tercantum dalam kurikulum 2013 serta kesesuaiannya dengan tingkat kemampuan siswa.

Dari hasil penelitian ini, peneliti menyarankan guru-guru Bahasa Indonesia untuk menggunakan novel Kaliluna: Luka di Salamanca karya Ruwi Mwita sebagai materi pembelajaran sastra di sekolah. Selain itu, baik guru maupun sekolah, perlu menyediakan bahan bacaan perkembangan usia anak. 


\section{REFERENSI}

Ambarini, Ririn. (2008). "Konflik Batin Dolour Darcy Pendekatan Psikoanalisis Freud Terhadap Tokoh Utama Novel Poor Man's Orange Karya Ruth Park". Universitas Diponegoro Semarang. Thesis dipublikasikan. Diakses pada 13 April 2018 dari https://scholar.google.com.

Lestari, Ika. (2013). Pengembangan Bahan Ajar Berbasis Kompetensi. Padang: Akademia Permata.

Minderop, A. (2013). Psikologi Sastra: Karya Sastra, Metode, Teori, dan Contoh Kasus. Jakarta: Yayasan Pustaka Obor Indonesia.

Ni'mah, Aisyah. (2017). Mekanisme Pertahanan Ego Fukushima Akira dalam Film Dare Mo Shiranai Kalian Psikologi Sastra. Universitas Diponegoro Semarang. Skripsi ini diakses pada 21 April 2018.
Rahmanto, B. (1998). Metode Pengajaran Sastra. Yogyakarta: Kanisius.

Ratna, N. K. (2004). Teori, Metode dan Teknik Penelitian Sastra. Yogyakarta: Pustaka Pelajar.

Rini, Agustian Pangestu. (2014). Konflik Batin Tokoh Utama Dalam Novel Bidadari-Bidadari Surga Karya Tere Liye (Kajian Psikologi Sastra). UNS. Skripsi ini diakses pada 14 Maret 2018 dari https://digilib.uns.ac.id/dokumen/det ail/3694/Konflik-Batin-TokohUtama-Dalam-Novel-BidadariBidadari-Surga-Karya-Tere-LiyeKajian-Psikologi-Sastra

Sobur, Alex. (2013). Psikologi Umum. Bandung: Pustaka Setia.

Waluyo, Herman J. (2011). Pengkajian dan Apresiasi Prosa Fiksi. Surakarta: UNS Press. 